\title{
Ethanolic Extract of Secang Heartwood (Caesalpinia sappan L.) Increases Bone Density in Ovariectomized Rats
}

\author{
Bani Adlina Shabrina, Nita Kristiani, Khairunisa Irnanda, Fajar Aji Lumakso, \\ Riris Istighfari Jenie*
}

Cancer Chemoprevention Research Center, Faculty of Pharmacy, Universitas Gadjah Mada, Yogyakarta, Indonesia

\begin{abstract}
Osteoporosis has become a major public health concern, due to its rising incidence every year. Osteoporosis mostly occurs in women at menopause, especially in Asia. Secang (Caesalpinia sappan L.) heartwood contains brazilin and brazilein which are known to suppress expression of NF-KB, an osteoclastogenesis protein playing an important role in osteoporosis. Thus, the aim of this research is to investigate the inhibition of osteoporosis by ethanolic extract of secang (Caesalpinia sappan L.) (EES) in ovariectomized (OVX) rats. Thirty female Sprague Dawley rats were divided into five groups treated for 20 days: group I were OVX and treated with $1000 \mathrm{mg} / \mathrm{kgBW}$ EES; group II were OVX and treated with 500 $\mathrm{mg} / \mathrm{kgBW}$ EES; group III were OVX and treated with CMC-Na; group IV were shame OVX baseline; and group $V$ were non-OVX-baseline. Bone density was examined by using $X-R a y$ rontgen and was strengthen by qualitative data of Giemsa staining. Moreover, total number of osteoclasts in bone slide was observed by TRAP expression using double staining immunohistochemistry with hematoxylin eosin (HE)-TRAP. Treatment of $500 \mathrm{mg} / \mathrm{kgBW}$ EES in ovariectomized rats showed the highest bone density of $0.60 \mathrm{gr} / \mathrm{cm}^{3}$ and the lowest number of osteoclasts was 4.66 osteoclasts per field of view. These results showed that EES is potent to be developed as an antiosteoporosis agent. Further study on its dose adjustment and molecular mechanism needs to be conducted.
\end{abstract}

Keywords: Caesalpinia sappan L., osteoporosis, RANK, bone density

\section{INTRODUCTION}

Postmenopausal osteoporosis is a major female health problem that increases morbidity, mortality and healthcare system costs (Mendozaa, et al., 2013). Changes in body composition with aging and menopause, especially bone mass loss, have been associated with increased morbidity and mortality which predisposes to falls and osteoporosis fractures (Douchi, et al., 2002). Osteoporosis is estimated to affect 200 million women worldwide-approximately one-tenth of women aged 60, one-fifth of women aged 70, two-fifths of women aged 80 and two-thirds of women aged 90 . Besides that, osteoporosis causes more than 8.9 million fractures annually, resulting in an osteoporotic fracture every 3 seconds (Admin International Osteoporosis Fondation, 2013).
Secang (Caesalpinia sappan L.) heartwood has been reported as an antiosteoporosis agent with the important role of its content, flavonoids. Batubara, et al., 2010, reported that secang heartwood contain flavonoid and fenolic active compound, such as 4-0-methyl sapanol, protosappanin A, protosappanin $\mathrm{B}$, protosappanin $\mathrm{E}$, brazilin, brazilein, caesalpini, brazilide $\mathrm{A}$, neosapanone, and 7,3,4-trihidroksi-3-benzil-2H. Flavonoids have activity to prevent osteoclastogenesis in NF-kB pathway (Yamamoto and Gaynor, 2001).

The aim of this study is to observe anti-osteoporosis activity of EES in vivo. EES was given to the ovariectomized female Sprague Dawley rats as model of osteoporosis.

*Corresponding author e-mail: riris.jenie@gmail.com 
Parameters which are observed in this study were bone density and bone slide histopathology using Giemsa and TRAP (tartrate-resistant acid phosphatase) staining methods. This study is a preliminary study to reveal potency of secang as anti-osteoporosis agent.

\section{MATERIALS AND METHODS}

\section{Plant Collection and Identification}

Powder of secang (Caesalpinia sappan L.) was obtained from B2P2TOOT, Tawangmangu, Central Java in February 2013 and was identified. Powder was extracted by maceration for 5 days with $70 \%$ ethanol (E.Merck, Darmstadt, Germany). The filtrate was then evaporated by using vacuum rotary evaporator.

\section{Animals}

A total of 30 female Sprague Dawley rats (6 weeks), weighed from 86 to $112 \mathrm{~g}$ were purchased from Unit Pengembangan Hewan Percobaan Universitas Gadjah Mada. The animals were adapted for at least one week before treatment. The rats were given standard pellet diet and water ad libitum, with $12: 12 \mathrm{~h}$ light/dark cycle.

\section{Experimental Procedure}

All animals were divided into 5 groups, 6 rats in each group. The experimental design is summarized in Table 1. Group 1 ovariectomized (OVX)+EES 1000mg/kgBW; Group 2 ovariectomized (OVX)+EES $500 \mathrm{mg} / \mathrm{kgBW}$; Group 3 ovariectomized $(\mathrm{OVX})+\mathrm{CMC}-\mathrm{Na}$ as solven control; Group 4 shame ovariectomized $(\mathrm{OVX})+\mathrm{CMC}-\mathrm{Na}$; and Group 5 non-ovariectomized (non-OVX). All groups were treated with EES or CMC-Na solution for 20 days.

On the $22^{\text {nd }}$ day, all animals were sacrified, then left and right femur bones were collected. Femur bones were cleaned and soaked in saline $0.9 \%$. Right femur bone was then fixed in $10 \%$ formalin and stained with TRAP and Giemsa. Left femur bone was examined by rontgen to determine the bone density.

\section{Data Analysis}

Macroscopic analysis was done using $\mathrm{X}$-ray rontgen and resulted in bone density $\left(\mathrm{g} / \mathrm{cm}^{3}\right)$. Bone density measurement was done in Basic Physics Laboratory, Faculty of Mathematic and Natural Science, UGM. While microscopic analysis was done by counting osteoclast on bone slide stained with Giemsa and haematoxylin eosin (HE)-TRAP.

\section{RESULTS AND DISCUSSION}

\section{Extraction and Qualitative Analysis of Ethanolic Extract of Secang (EES)}

Extraction process of secang by maceration using $70 \%$ ethanol and 51.24 gram of viscous extract was obtained. Yield of the resulting extract is equal to $10.24 \% \mathrm{w} / \mathrm{v}$.

\section{Effects of EES on Bone Density}

Bone density was determined using $\mathrm{X}$ ray to compare bone density of ovariectomized (OVX) rats from each treatment group (Fig. 1). Moreover, histopathology of bone density matrix was also observed by using Giemsa staining (Fig. 2).

The higher the density the bone matrix, the less the number of osteoclasts, giving a better bone density profile. The result of this study showed that ovarectomized rats (group 3) decreased the bone density $\left(0.52 \mathrm{~g} / \mathrm{cm}^{3}\right)$ and group 2 treated with $500 \mathrm{mg} / \mathrm{KgBW}$ EES tend toincreased bone density $\left(0.60 \mathrm{~g} / \mathrm{cm}^{3}\right)$. Moreover, group 2 has higher density than control (group 5) shown at (Fig. 1) based on both X-ray rontgen and Giemsa staining (Fig. 2).

Table I. Experimental Design

\begin{tabular}{|c|c|c|}
\hline Experimental group & $\begin{array}{l}\text { The Number of } \\
\text { Female Sprague } \\
\text { Dawley rats/group }\end{array}$ & Dose Frequency \\
\hline I. OVX+EES $1000 \mathrm{mg} / \mathrm{kgBW}$ & 6 & \multirow{5}{*}{ Once a day for 20 days } \\
\hline 2. OVX+EES $500 \mathrm{mg} / \mathrm{kgBW}$ & 6 & \\
\hline 3. $\mathrm{OVX}+\mathrm{CMC}-\mathrm{Na}$ & 6 & \\
\hline 4. Shame OVX+CMC-Na & 6 & \\
\hline 5. Non-OVX+CMC-Na & 6 & \\
\hline
\end{tabular}




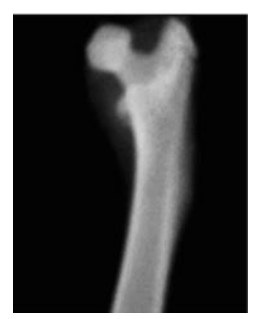

(A)

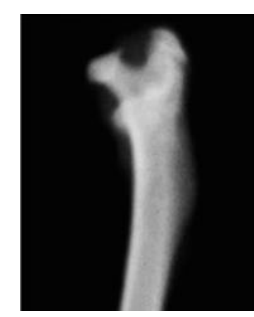

(B)

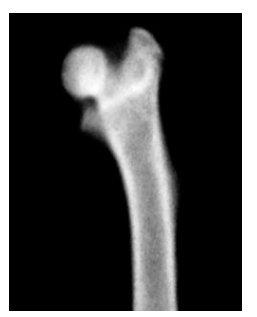

(C)

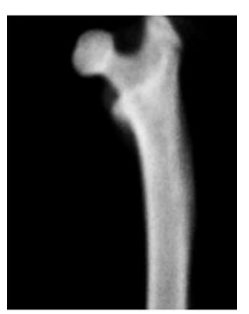

(D)

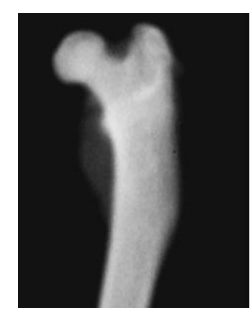

(E)

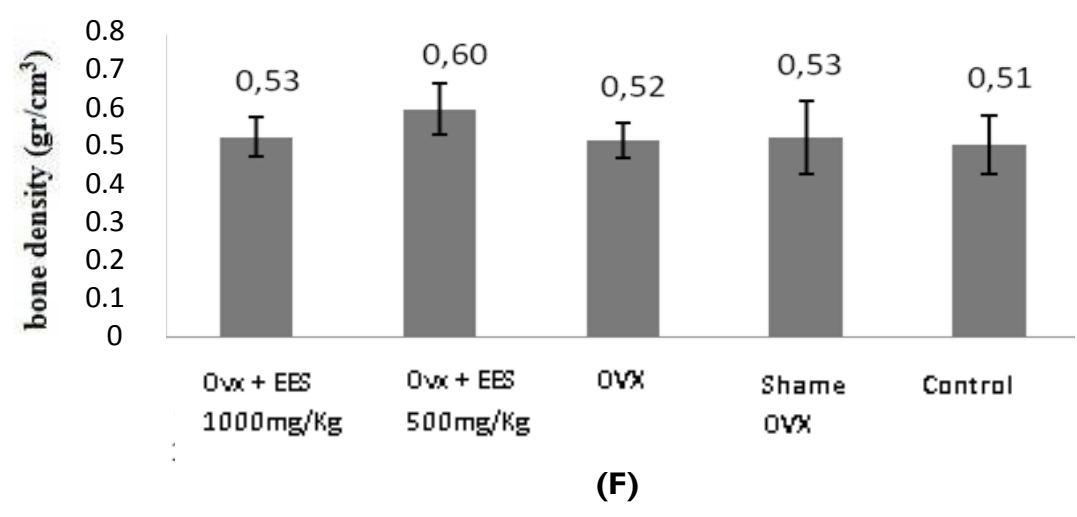

Figure I. Effects of EES on Bone Density. Femur from each group were analyzed by using X-ray rontgen as described in methods. The X-ray image of femur bone of (a) Group I (OVX + EES $1000 \mathrm{mg} / \mathrm{kgBW}$, (b) Group 2 (OVX + EES 500 mg/kgBW), (c) Group 3 (OVX), (d) Group 4 (shame-OVX), and (e) Group 5 (control, non-OVX); (f) X-ray image the quantified to compare effect of EES on bone density. Each bar was mean from 6 animals.

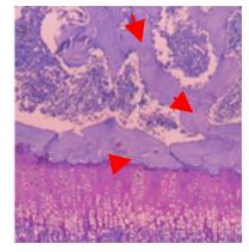

(A)

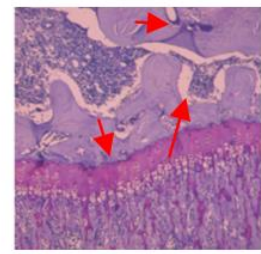

(B)

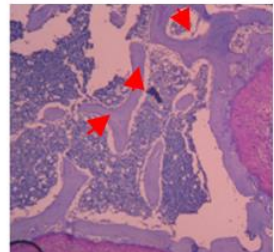

(C)

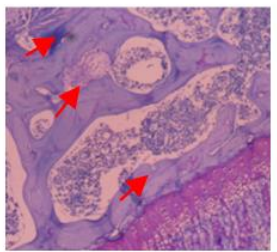

(D)

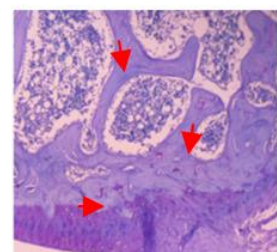

(E)

Figure 2. Histopathology of bone density matrix. The femur bone slide was stained with Giemsa to analyze the bone density matrix as described in the methods. Bone histopathology of (a) Group I (OVX + EES $1000 \mathrm{mg} / \mathrm{kgBW}$, (b) Group 2 (OVX + EES $500 \mathrm{mg} / \mathrm{kgBW}$ ), (c) Group 3 (OVX), (d) Group 4 (shameOVX), (e) Group 5 (Control non OVX). Red arrows $(\longrightarrow$ ) showed the bone matrix. Slide was observed under light microscope with 400 times magnification.

The group treated with EES 500 $\mathrm{mg} / \mathrm{KgBW}$ showed the thickest bone matrix and tend to be similar to control group. Qualitative and quantitative bone densityshowed that 500 $\mathrm{mg} / \mathrm{KgBW}$ EES give the thickest bone density. These results suggest that EES increase density of bone matrix as seen at Fig. 1 and Fig. 2.

\section{Effects of EES on Osteoclast Formation}

Recently, it has been reported that lower TRAP expression reflects better bone density
(Alatalo, et al., 2000). TRAP is secreted by osteoclast and and hence is used as the marker of osteoclasts differentiation. Osteoclast is a characterized cell involved in bone resorbtion. TRAP staining is conducted to stain the osteoclast. TRAP is a protein which is highly expressed when osteoclast differentiation occures. Both dose of $500 \mathrm{mg} / \mathrm{kgBW}$ EES (group 2) and $1000 \mathrm{mg} / \mathrm{kgBW}$ EES (group 1) on ovariectomized rats decreased osteoclast formation compared to control of 
ovariectomized rats (group 3). The osteoclast score of 46.30 osteoclast per field of view at ovariectomized rats (group 3) and 4.66 osteoclast per field of viewat $500 \mathrm{mg} / \mathrm{KgBW}$ EES treated group (group 2) (Fig. 3B and 3C). Even, $500 \mathrm{mg} / \mathrm{kgBW}$ EES gave better profile rather than control non-ovariectomized (group 5) (Fig. 3B and 3E). These results suggested that EES $500 \mathrm{mg} / \mathrm{KgBW}$ can be developed as an potential anti-osteoporosis agent targetted in osteoclast formation inhibition.

RANKL plays an important role in the differentiation and activation of osteoclasts. RANKL is a member of the TNF (Tumor Necrosis Factor) that is expressed by macrophages and can interact with its receptor (RANK) (Theill, et al., 2002). Interaction of RANK and RANKL can induce differentiation of osteoclast precursor, stimulates bone resorption, and maintaining mature osteoclasts. Continued with the activation of TRAF (TNF Receptor-Associated Factor) protein. TRAF6 protein is a protein that is involved in RANK downstream protein signaling. TAK-1/TAB 2 complex activates TRAF6 to activate NF- $\kappa \mathrm{B}$ and JNK (c-jun N-terminal Kinase). NF- $\kappa \mathrm{B}$ in the cytoplasm is inactive because of the binding of inhibitor protein I $\kappa \mathrm{B}$ (Inhibitor of Kappa Light Chain Gene Enhancer in B-cells). Activation of $\mathrm{NF}-\kappa \mathrm{B}$ caused by the degradation of $\mathrm{I} \kappa \mathrm{B}$ leads to the transport of free NF- $\kappa \mathrm{Bt}$ into the nucleus that later will bind to DNA.

The results of gene transcription expressing osteoclasts makethe cells can differentiate into mature osteoclasts (Jimi et al, 1999).

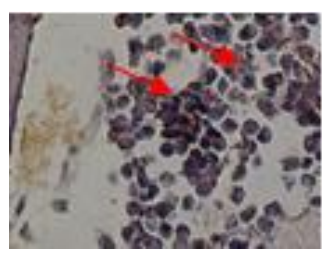

(A)

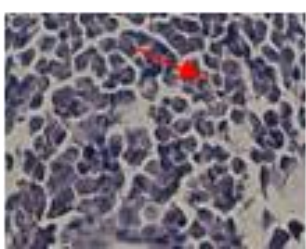

(B)

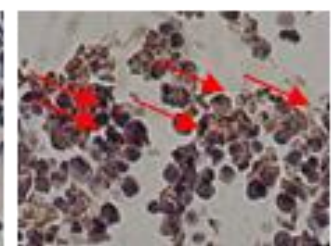

(C)

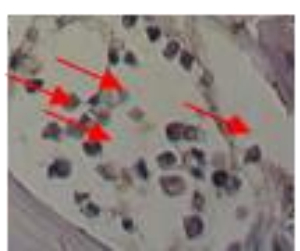

(D)

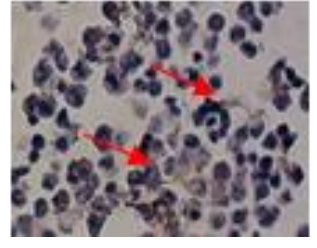

(E)
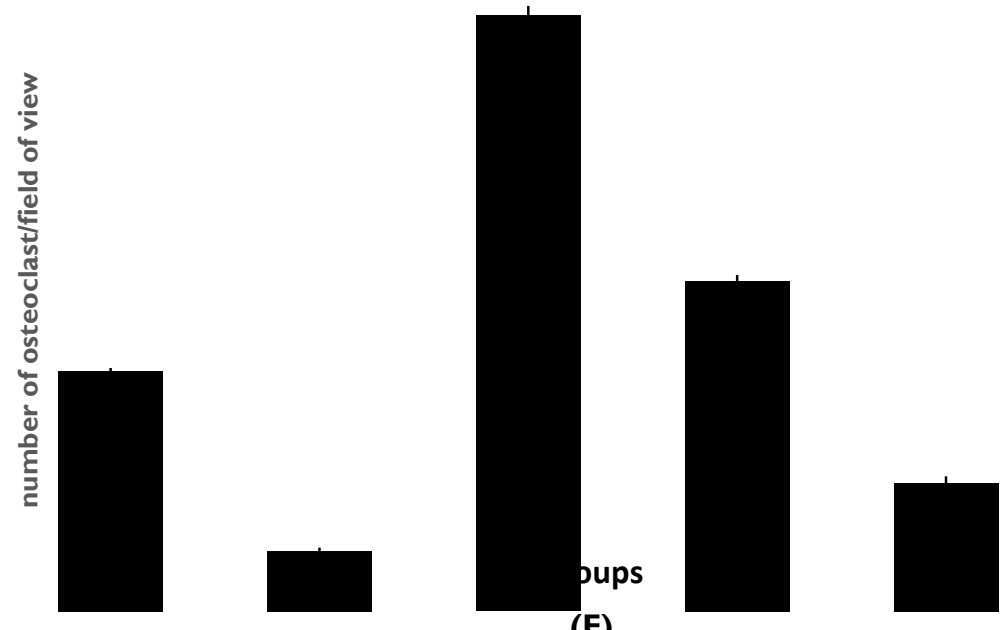

Figure 3. Effect of EES on osteoclast formation. Femur bone slide was stained with TRAP antibody using immunohistochemistry as described in the methods. Bone slide of (a) Group I (OVX + EES 1000 $\mathrm{mg} / \mathrm{kgBW}$, (b) Group 2 (OVX + EES 500 mg/kgBW), (c) Group 3 (OVX), (d) Group 4 (shame-OVX), (e) Group 5 (Control non OVX). Red arrows $(\longrightarrow$ ) showed osteoclast formation. Slide was observed under light microscope with 400x magnification. (f) EES treated groups gave lower number of osteoclast compared to OVX group. 
Administration of EES at dose 500 $\mathrm{mg} / \mathrm{KgBW}$ to ovariectomized rats increasedbone density. The increase of bone density observed in this study was related to the inhibition of osteoclast formation. Based on previous study, EES interferes NF- $\kappa B$ pathway. Shengqian (2011) reported that EES significantly suppressed IL1 $\beta$-mediated upregulation of MMP-13 mRNA and protein levels via abrogation of the NF- $\mathrm{kB}$ (p65/p50)driven MMP-13 promoter activation. Extract of Caesalpinia sappan L. shows significant estrogenic effect through increasing SEAP (Secreted Alkaline Phosphatase) activity in MCF-7 cells (Lai, et al., 2011). Thus, EES mechanism inhibiting osteoclast formation can be caused of NF- $\mathrm{KB}$ pathway alteration.

Another pathway might be mechanism of EES as anti-osteoporosis agent. Beside brazilin and brazilein, compounds in EES perform as phytoestrogen, such as deoxysappanone, deoxysappanchalcone, and protosappanin (Lai, et al., 2011). Therefore, those compounds might perform as exogenous estrogen in postmenopausal women. Further explorations on both mechanism of EES inhibiting osteoporosis, estrogenic effect and NF- $\mathrm{KB}$ pathway alteration, are needed to developed EES as anti-osteoporosis agent.

\section{ACKNOWLEDGEMENT}

We acknowledge Directorate General of Higher Education, Ministry of Education and Culture, Republic of Indonesia who has funded this research in 2011.

\section{REFERENCES}

Alatalo, S.L., Halleen, J.M., Hentunen, T.A., Mönkkönen, J. and Väänänen, H.K., 2000, Rapid Screening Method for Osteoclast Differentiation in Vitro That Measures Tartrate-resistant Acid Phosphatase Activity Secreted into the Culture Medium, Clinical Chemistry, 46(II), I75I-I754.

Batubara, I., Darusman, L.K., Mitsunaga, T., Rahminiwati, M. and Djauhari, E., 2010, Potency of Indonesian Medicinal Plants as Tyrosinase Inhibitor and Antioxidant Agent, Journal of Biological Sciences, I 0(2), I38-I44.

Capparelli, C., Kostenuik, P.J., Morony, S., Starnes, C., Weimann, B., Van, G., et al., 2000, Osteoprotegerin prevents and reverses hypercalcemia in a murine model of humoral hypercalcemia of malignancy, Cancer Research, 60(4), 783-787.

Douchi, T., Yamamoto, S., Yoshimitsu, N., Andoh, T., Matsuo, T. and Nagata, Y., 2002, Relative contribution of aging and menopause to changes in lean and fat mass in segmental regions, Maturitas, 42, 30I-306.

Jimi, E., Akiyama S., Tsurukai T., Okahashi N., Kobayashi K., Udagawa N., et al., 1999, Osteoclast Differentiation Factor Acts as a Multifunctional Regulator in Murine Osteoclast Differentiation and Function, J. Immunol., I 63(I), 434-42.

Lai, W.C., Wang, H.C., Chen, G.Y., Yang, J.C., Korinek, M., Hsieh, C.J., et al., 20II, Using the pER8:GUS Reporter System to Screen for Phytoestrogens from Caesalpinia sappan, J. Nat. Prod., 74(8), 1698-706.

Mendoza, N., Sánchez-Borrego, R., Villero, J., Baró, F., Calaf, J., Cancelo, M.J., et al., 2013, 2013 Up-date of the Consensus Statement of the Spanish Menopause Society on Postmenopausal Osteoporosis, Maturitas, 76(I), 99107.

Naito, K.T., 2008, Aldehydic Components of Cinnamon Bark Extract Suppresses RANKL-Induced Osteoclastogenesis Through NFATcl downregulation, Bioorg. Med. Chem., 16(20), 9176-9183.

Wu, S.Q., Otero, M., Ungera, F.M., Goldring, M.B., Phrutivorapongkul, A., Chiari, C., et al., 20II, Anti-inflammatory Activity of an Ethanolic Caesalpinia sappan Extract in Human Chondrocytes and Macrophages, J. Ethnopharmacol., I38(2), 364-372.

Simonet, W.S., Lacey, D.L., Dunstan, C.R., Kelley, M., Chang, M.S., Luthy, R., et al., 1997, Osteoprotegerin: a Novel Secreted Protein Involved in the Regulation of Bone Density, Cell, 89(2), 309-319.

Theill, L.E., Boyle, W.J. and Penninger, J.M., 2002, RANK-L and RANK: T-cells, 
Bone Loss, and Mammalian Evolution, Annu. Rey Immunol., 20(I), 795-823.

Yamamoto, Y. and Gaynor, R.B., 200I, Therapeutic Potential of Inhibition of the NF-kappaB Pathway in the Treatment of Inflammation and Cancer, J. Clin. Invest., 107(2), 135142. 